\title{
FIRST CHURCH AND FIRST SCHOOL IN LOWELL
}

\author{
By Charles R. Jackman ${ }^{1}$
}

\section{The First Church}

More than ninety years ago when the first church was built in what is now Lowell, Henry County, Iowa, was still in its real pioneer stage. Indians were common, although there was quite a settlement in the vicinity. Its first settler was Hiram C. Smith who came here with his family on May 8, 1833. A grist and sawmill was early built and the place came to be known as Smith's Mills, being named after the first settler.

M. M. MeCarver, who was one of the first settlers of Burlington, on November 13, 14, 16, and 17, 1840, surveyed and platted the place as a village and named it MeCarverstown. Within a few days a committee of citizens bargained with him for a church site on the northeast corner of Clark and Third streets. Soon almost every man in the community, regardless of denomination or creed, was busy, some cutting logs, some with ox teams hauling them to the church lot, while others were hewing and shaping them for the building. And then came the raising, always a big day with the pioneers.

The church was quite a commodious building for a frontier church. The roof was of clapboards. There were two windows on each side, and a very large fireplace in the end of the building. The seats were made of plank with wooden pins for legs, but had no backs. For the first three or four years there was no floor. There had stood on the lot on which the building was erected a large oak tree, and as it would have required much work to remove this stump, it was cut down to the proper height and left for the desk in the pulpit. The door was of heavy plank with wooden hinges, and a latch and string.

The building was completed before the holidays, when there was a great rejoicing among the people. At last all of them had a place of worship, and especially the mothers and children had a place where they could meet and get acquainted with their

\footnotetext{
${ }^{1}$ Martha G. Smith came to Iowa May, 1833, at the age of six years with her parents and three brothers. She was the first white girl in the settlement. In 1853 she married Clarkson Jackman. They are the parents of the writer of this article. They lived out their lives on the old homestead. The writer's home is only about 100 feet from the site of his grandfather's first cabin. The ownership of this tract of land has remained in the family.
} 
neighbors, many of whom they had never met before. Friendships were formed that endured throughout their lives. The building was used by all denominations that wanted it.

These were really trying times. The people were poor in purse only. Their families were usually large and their homes mostly one room log cabins, with the barest of necessities. If they required more rooms, blankets or quilts were hung over poles or lines for partitions to make more rooms. But today we think of them only as "happy pioneers."

About the time the church was completed Edmund Archibald became the owner of the town site and he told the builders that he would make a deed for the property to the first church organization that asked for it if agreeable with the builders. He also petitioned the legislature to change the name from McCarverstown to Lowell, after the name of Lowell, Massachusetts, his native state, which was granted in January, 1844.

We find of record the following: "Edmund Archibald, and Belinda Archibald, his wife, for the consideration of fifteen dollars convey lot 110 in the town of Lowell, Iowa, to James A. Stewart, John Mowery, Benjamin Ellison, Thomas Angel and George Wiggins, trustees of the Lowell Society of the Methodist Episcopal Church of the United States of America. G. E. Shelleday, Justice of the Peace. William Brown, Witness. Date, July 25, 1844."”

As far as available the following are the names of the pastors of this church: Rev. Father Cole, Rev. I. I. Stewart, Rev. Thomas M. Kirkpatrick (one of seven brothers, of whom six were pioneer preachers in Illinois, Missouri and Iowa), Rev. Daniel G. Cartwright, and Rev. Mike See, who had a wonderful voice and was very successful in his religious work at camp meetings and revivals.

Preachers in those days went from fort to settlement, and from cabin to cabin, some on horseback, but usually on foot with hardly a path or trail to follow, and walked on dirt floors for carpets. About their only reward was their board and lodging and their love for their work.

The church was destroyed by a storm in 1855, and never rebuilt. 


\section{The First School}

For the purpose of encouraging education Congress in 1841 enacted a law providing that section sixteen in each and every township where possible in the new states should not be subject to homestead, but reserved for the support of the organized districts of the common schools. By this measure the government appropriated one thirty-sixth part of its land to aid the work of education in the new states. In Iowa this amounted to about 100,000 acres.

As early as 1840 Henry Johnson could be seen wending his way from cabin to cabin of the settlers, teaching the children in their homes. As they had no books he gave them lessons that he had written on paper to study, coming back the next day and so on, the parents paying him so much per scholar.

On May 7, 1849, the citizens of I.owell and vicinity held a meeting for the purpose of organizing a school district, and the following school officers were elected: J. B. Miller, president; William Brown, treasurer; and Peter F. Anderson, secretary. They were authorized to set aside thirty dollars to pay for a three-months school at ten dollars per month, or so much per scholar if thought best.

After the organization of the district there were several terms of school taught in the Methodist Episcopal Church. Wooden pins were driven into holes made in the logs of the building, and boards laid on them for those who required desks. This was in the days of quill pens and keel pencils.

As far as known, the following are the names of the teachers who taught in the church building: Henry Johnson, W. C. Wiggins and Cinthia Ann Williams. The church building was destroyed by a tornado in 1855. We find this of record: "On May 13th 1856, Edmund Archibald, and Belinda Archibald, his wife, for the consideration of Ten-dollars Convey to the Lowell School District Lot 104 in the town of Lowell, Iowa, Being near the North-east corner of Third and Jefferson Street. John Grubb, Justice of the peace, James W. Smith, witness." The board contracted with Joseph Brown for the building of a frame schoolhouse of one room with seats for same. The building had four windows on each side, with a blackboard and rostrum both extending across the entire north end of the room. The seats were 
very large and strong. The building had room for one hundred and fifty scholars. Prior to this time no taxes had ever been levied to support the school, and the teachers were paid from the apportionment fund received from the state.

I was told that the first teacher in the new house was Charles Scarlet, who was followed by W. C. Wiggins, James Piper, Sarah E. Shelleday, Jane Chandler, Mark Swan, and possibly others. My own personal knowledge began when I entered school with Hans Wily, as teacher, followed by Ruth Dean, Samuel Blayney, Isaac M. Grubb, Margaret Williams, Hester Barr, Emily Knickerbocker, James H. Hobbs, Julia Dillon and Angie Beery. Hester Barr made teaching her life work, and is the only one of the above teachers now living. These were all fine teachers who faithfully and impartially performed their duties, receiving for their services for the summer school of sixty to eighty scholars, twenty to twenty-five dollars per month, and for the winter term with one hundred to one hundred and fifty scholars, twenty-five to thirty dollars per month. Spelling, writing, reading and arithmetic, with a small class in geography at the winter term, were the branches taught. I do not remember of any algebra, latin or grammar classes. It was not unusual to see girls and boys almost of age in the A-B-C class. When time permitted the teacher would hear the older scholars separate from the younger. The old blue-back speller (Webster's Elementary Speller) was first used, but later Ray's Arithmetic and McGuffey's spellers and readers were adopted.

I believe Angie Beery taught the last school in the old house. It was abandoned for school purposes, and a new one built on the corner of Clark and Fourth streets, and later moved to its present location.

As there was no church built in Lowell after the destruction of the old $\log$ one in 1855, all denominations that wished used the old schoolhouse, but it was mostly used by the Methodist Protestants, as they were then largely in the majority. There were many pastors on this circuit, many of them unknown to this writer, but probably Rev. Father Newel, whose home was near Danville, Iowa, was best and mostly known. He lived to a very old age, and was a friend to everybody.

The Old Schoolhouse was the center of all activities of the 
people of Lowell and vicinity. It was the scene of church, of Sunday school, of funerals, of school exhibitions, literary societies, and spelling contests, and magie lantern shows and others of that class. Public lectures and political meetings and elections were held in it. Governors, United States senstors, congressmen, and many other able and prominent orators have spoken from the old rostrum, usually commending their own party and condemning their opponents, amid great applause from their audiences.

It was also the seat of justice, as the justice of the peace held court there on Saturdays when there was any business on the docket, and some of the ablest lawyers of the day made the old walls ring with their pleas for their clients.

A few years ago the property was sold to a private party and was torn down. So ends the story of the first schoolhouse and school in Lowell.

\section{HOGS AT LARGE}

It was necessary not long since to call attention of the city authorities to the fact that hogs running at large in violation of law have done a great deal of mischief about town. The excuse given for the large liberty they enjoyed was that the January flood had washed away the pens in which they were immured and that they were consequently emancipated porkers. But the flood has spent its fury and there is now no further apology for continuing to violate the law. If our officers have any regard for the performance of duty they will at once clear the town of all loose hogs.-Daily State Register, Des Moines, Iowa, May 2, 1862. (In the Newspaper Division of the Historical, Memorial and Art Department of Iowa.) 
Copyright of Annals of Iowa is the property of State of Iowa, by \& through the State Historical Society of Iowa and its content may not be copied or emailed to multiple sites or posted to a listserv without the copyright holder's express written permission. However, users may print, download, or email articles for individual use. 